\title{
ТЕОРЕТИЧНІ АСПЕКТИ РЕСТРУКТУРИЗАЦІї ПІДПРИЕМСТВА ЯК ЕКОНОМІЧНОї КАТЕГОРІї
}

\author{
Кирчата І.М., канд. екон. наук, доцент
}

Харківський національний автомобільно-дорожній університет

Постановка проблеми в загальному вигляді та їі зв'язок з важливими науковими або практичними завданнями. Успішне функціонування підприємства в динамічних, а часто й кризових умовах конкурентної боротьби потребує від керівництва грамотного та професійного менеджменту: пошуку нестандартних рішень та бачення нових горизонтів своєї діяльності на ринку; володіння потенціалом і здатністю забезпечити поштовх для свого розвитку в стратегічній перспективі.

Слід відмітити, що кожне підприємство має свій рівень потенціалу реструктуризаційних змін, який можна активізувати не тільки задля забезпечення гідного рівня конкурентоспроможності, але й для елементарного протистояння динамічним факторам конкурентного середовища.

Управлінська ланка підприємства має чітко формулювати стратегічні орієнтири та прогнозувати зміни факторів зовнішнього середовища, а тому рішення задачі з адаптації до цих змін й обумовлює необхідність проведення процесу реструктуризації підприємств не залежно від їх галузевої приналежності.

В такому випадку реструктуризацію слід сприймати як перехід від одного режиму функціонування до такого, що адекватно реагує та своєчасно змінюється, чим й надає підприємству конкурентних переваг, з подальшою спроможністю виживати в довгостроковій перспективі.

Основними потенціально успішними передумовами проведення процесу реструктуризації є не стільки вибір вірного напряму стратегії реструктуризації, скільки послідовність реалізації організаційних змін в системі стратегічного 
управління. Саме процес реструктуризації потребує правильного й відповідного управлінського рішення оскільки по своїй природі має специфіку: використовує нові підходи, методи та технології (є інноваційно складним); має ризикову компоненту (неотримання очікуваного результату); виступає складним структурованим процесом.

Аналіз останніх досліджень і публікацій, в яких покладений початок вирішенню даної проблеми і на які спирається автор.

Будучи актуальним явищем реструктуризація залишається дискусійною категорією, а тому єдиного підходу до вирішення проблем реструктуризації підприємств наразі не існує, при цьому переважна більшість публікацій не має універсальної методології, системності, цілісності і несуперечності.

Сутність поняття «реструктуризація» ще у 80 -х роках $\mathrm{XX}$ століття висвітлювалась в працях таких зарубіжних вчених, як М. Портер, Т. Пітерс, А. Стрікленд, М. Хамер та ін. Реструктуризація трактувалась як сукупність стратегічних заходів щодо перетворення структури диверсифікованої компанії шляхом продажу одних напрямів діяльності і придбання інших [1].

Німецькі учені Э. Фрезі і Л. Тойфсен з Кельнського університету вважають, що процес реструктуризації полягає і стосується тільки перетворення структури управління [2].

Вчені К. Кордан. Т. Фолмэн і М. Вандерборт вважають, що результатом проведення реструктуризації підприємства мають стати сучасніші продукти, а не тільки здатність працювати краще [3].

«Реструктуризація» (restructuring, у перекладі 3 англійської) - це перебудова структури чого-небудь, яка необхідна в ситуаціях коли: підприємство знаходиться в стані глибокої кризи (антикризова реструктуризація); поточний стан підприємства можна визнати як задовільний, проте прогнози його діяльності не $є$ оптимістичними (функціональна реструктуризація); до реструктуризації можуть удатися успішні підприємства 3 метою створення унікальних конкурентних переваг (стратегічна реструктуризація) [4]. 
На думку М. Дмитрієва, основною задачею реструктуризації бізнесу є створення такої бізнес-системи, яка, 3 одного боку, відповідатиме довгостроковим задачам власників, а з іншого - буде розвиватися відповідно до вимог навколишнього середовища [5].

Реструктуризація $€$ інструментом антикризового управління 3 особливостями структурних перетворень як окремих складових елементів підприємства, так і всієї їх сукупності. Реструктуризація направлена на вдосконалення фінансово-економічних аспектів господарської діяльності та узгодження підприємницької структури із злім середовищем у напрямку відповідності законодавчим вимогам, удово-технічному прогресу, підвищення конкурентоспроможності [6]

На думку Ж. Крисько, „реструктуризація - це зміна структури економічного суб’єкта (активів, власності, фінансів, управління) незалежно від його стану під впливом чинників зовнішнього і внутрішнього середовища для підвищення конкурентоспроможності 3 подальшим зростанням вартості бізнесу [7].

Формування й реалізація процесу реструктуризації виступає складним та тривалим процесом, що передбачає наявність організаційно-економічних, виробничих, фінансових, правових, інноваційних, інвестиційних складових, які мають злагоджено функціонувати та сприяти розвитку структурних елементів підприємства як системи в цілому.

Невирішені складові загальної проблеми. Практика вітчизняних підприємств доводить об’єктивну необхідність реструктуризації, проте керівництво має чітко визнати наявність потреби в змінах, необхідність переформування власної системи управління з урахуванням загальної ситуації та наявних конкурентних переваг.

В сучасних умовах можливість правильно виділити i розвинути конкурентну перевагу стає основною проблемою метою реструктуризації суб'єктів господарювання, при цьому серед найактуальніших методичних проблем процесу реструктуризації залишаються наступні: проблема 
обгрунтування необхідності реструктуризації на основі діагности його конкурентного потенціалу; проблема підготовки самого процесу реструктуризації; проблема ефективної адаптації підприємства до конкурентних умов; проблема розвитку конкурентного потенціалу; проблема збереження конкурентної стійкості.

Дозволяючи правильно виділити і розвинути конкурентну перевагу, реструктуризація стає високоефективним ринковим інструментом підвищення конкурентоспроможності підприємства, оскільки основними ідеями останньої $є$ адаптація підприємства до факторів зовнішнього середовища, а також ідея комплексного підходу до рішення складних управлінських задач в часто кризових умовах.

Формулювання мети статті (постановка завдання). Дослідженню проблематики реструктуризації господарських суб'єктів присвячено наукові роботи багатьох вітчизняних та зарубіжних науковців, проте й досі виникають суперечності щодо існування взаємозв'язку 3 суміжними категоріями (реорганізація, реформування, реінжиніринг), а виокремлення основних підходів в трактуванні категорії «реструктуризація» й наразі актуальне.

Відсутність єдиного підходу до змісту і сутності реструктуризації в категоріальному апараті обумовлює необхідність розділити всі ці поняття, при цьому спробувати водночас поєднати їх в єдиній системі, тим самим структурувати процес змін і переходу на новий рівень розвитку підприємств.

Викладення основного матеріалу дослідження 3 повним обгрунтуванням отриманих наукових результатів. Ефективні керівники мають постійно проводити системні перетворення на своїх підприємствам задля вчасного пристосування до нових умов ведення бізнесу, а реструктуризація в цьому випадку є саме інструментом попередження та уникнення багатьох проблем: скорочення обсягів виробництва, падіння рівня прибутку та незадовільний рівень рентабельності, зростання витрат та застарілі технології та ін.

3 позицій системного підходу: 
,,реструктуризація - це процес впровадження структурних змін в діяльність підприємства 3 метою збереження та підвищення прибутковості під впливом мінливих зовнішніх економічних умов“" [8];

„,реструктуризація - комплекс заходів спрямованих на підвищення вартості бізнеса діючого підприємства" [9];

„реструктуризація - комплексна оптимізація системи функціонування підприємства відповідно до вимог зовнішнього оточення і виробленої стратегії його розвитку, сприяюча принциповому поліпшенню управління, підвищенню ефективності і конкурентоспроможності виробництва i продукції, що випускається, на базі сучасних підходів до управління, у тому числі методології управління якістю, реінжинирінга бізнес-процесів, інформаційних технологій i систем та ін" [10].

Виходячи 3 того, що діяльність будь-якого підприємства орієнтована на досягнення оптимального співвідношення між прибутковістю і стабільністю, основною метою реструктуризації $є$ забезпечення необхідних умов реалізації системних перетворень для досягнення такого балансу на засадах: забезпечення переходу системи в якісно новий стан; скорочення термінів досягнення нового рівня розвитку; забезпечення адаптаційних якостей; сприяння концентрації ресурсів на процесах розвитку; забезпечення ефективності процесів управління та ін.

Наступним кроком повинні бути задіяні механізми використання наявних конкурентних переваг, що є у підприємства, залучені фінансові ресурси через підвищення інвестиційної привабливості і сформована ефективна система управління.

Наряду з терміном «реструктуризація» в науковій думці та на практиці має місце застосування поняття «реорганізація», якому відведено місце як вид реструктуризаційних заходів або як окремий напрям.

Розглядаючи підприємство як складну систему, схильну до впливу чинників різного рівня, то ототожнення реструктуризації і реформування, ймовірно, відбувається тому, що мета у них спільна - адекватна реакція 
підприємства на зміни зовнішнього конкурентного середовища, як господарчого суб’єкта, та відповідна адаптація до них.

Реструктуризація, виступаючи першочерговою складовою процесу реформування підприємства, розуміється у вужчому сенсі і реалізує себе як один з інструментів досягнення його довгострокових стратегічних цілей.

Узагальнюючи результати досліджень 3 проблем реструктуризації в діловій і науково-популярній літературі, можна відмітити, що іiі дуже часто ототожнюють 3 процесами реформування, реорганізаційних змін та реінжинірингу бізнес-процесів (табл. 1).

Досліджуючи взаємозв’язок категорій «реформування - реструктуризація - реорганізація - реінжиніринг» та їх сутності можна зробити висновок, що реструктуризація: передбачає комплексність перетворень і змін, а не зміни тільки в одній функціональній сфері (маркетинг, фінанси, виробництво); $є$ постійним інструментом управління, а не реалізацію разового заходу; в змозі поєднувати майнові перетворення як елемент змін та підлягає модифікації і коригуванню в ході реалізації.

Головною метою реструктуризації в цьому випадку стає пошук джерел розвитку підприємства та дотримання наступних вимог: збереження та розвиток наукового, технологічного, виробничого і кадрового потенціалу; узгодження інтересів власників, працівників, менеджерів, основних кредиторів i т.д.); рішення проблеми погашення заборгованості перед бюджетом, державними позабюджетними фондами, своїми працівниками та ін.; збільшення реальних надходжень до бюджету i державних позабюджетних фондів; максимально можливе збереження і створення нових робочих місць; захист і дотримання прав акціонерів, учасників і працівників, передбачених чинним законодавством, колективними договорами і угодами. 


\section{Основні підходи до визначення сутності та співвідношення категорій} «реформування - реструктуризація - реорганізація - реінжиніринг» $[1,11,12]$

\begin{tabular}{|c|c|}
\hline Автор & Поняття \\
\hline \multicolumn{2}{|r|}{ Співвідночення „реструктуризачія і реформування” } \\
\hline $\begin{array}{l}\text { Бондар Н.П., } \\
\text { Васюхін О.В., } \\
\text { Голубєв А.А. }\end{array}$ & Реструктуризація - це структурне реформування \\
\hline Серкіна Н.А. & $\begin{array}{l}\text { Реструктуризація - один з методів реформування шляхом проведення } \\
\text { перетворень в організаційній, фінансово-економічній, виробнич- } \\
\text { технічній та соціальних підсистемах } 3 \text { метою адаптації до швидко } \\
\text { змінюваних умов зовнішнього середовища }\end{array}$ \\
\hline $\begin{array}{l}\text { Бузановский С.С., } \\
\text { Горелов Н.А., } \\
\text { Титков А.С. }\end{array}$ & $\begin{array}{l}\text { Реструктуризація - це структурна перебудова } 3 \text { метою забезпечення } \\
\text { ефективного розподілу та використання ресурсів }\end{array}$ \\
\hline Королькова О.М. & $\begin{array}{l}\text { Реформування - зміна принципів дії підприємства, що сприяє } \\
\text { підвищенню ефективності виробництва }\end{array}$ \\
\hline Скочиляс С. & Реформування -результат еволюції реструктуризації \\
\hline Аістова М.Д. & $\begin{array}{l}\text { Реструктуризація - частина загального розвитку підприємства, яку можна } \\
\text { розглядати як один з ключових механізмів реформування, що призводить } \\
\text { до збільшеня ефективності діяльності підприємства }\end{array}$ \\
\hline \multicolumn{2}{|r|}{ Співвідношення „,реструктуризація і реорганізація” } \\
\hline $\begin{array}{l}\text { Ільдеменов С.В., } \\
\text { Леонтьев С.В. }\end{array}$ & $\begin{array}{l}\text { Реструктуризація це структурна реорганізація підприємства, а також } \\
\text { комплекс робіт } 3 \text { активізації внутрішнього потенціалу }\end{array}$ \\
\hline $\begin{array}{l}\text { Жигунова О.А., } \\
\text { Чернявський } \\
\text { Ю.М. }\end{array}$ & $\begin{array}{l}\text { Реструктуризація - це структурна реорганізація підприємства, що } \\
\text { супроводжується в ряді випадків інституціональними змінами. }\end{array}$ \\
\hline $\begin{array}{l}\text { Тренев В.Н., } \\
\text { Іріков В.А. }\end{array}$ & $\begin{array}{l}\text { Реструктуризація - це реорганізація і комплексна зміна структури } \\
\text { підприємства та системи управління }\end{array}$ \\
\hline Євсеєв А.І. & $\begin{array}{l}\text { Реструктуризація - це будь-які зміни в виробництві, структурі капіталу } \\
\text { або власності, що не є частиною ділового повсякденного циклу компанії }\end{array}$ \\
\hline $\begin{array}{l}\text { Крижановскій } \\
\text { В.Г., Перелигіна } \\
\text { А.В. }\end{array}$ & $\begin{array}{l}\text { Реструктуризація - це структурна перебудова з метою забезпечення та } \\
\text { використання всіх ресурсів підприємства, що полягає в створенні } \\
\text { комплексу бізнес-одиниць на основі розділу, поєднання, ліквідації діючих } \\
\text { в організації нових структурних підрозділів. }\end{array}$ \\
\hline \multirow[t]{2}{*}{ Королькова О.М. } & $\begin{array}{l}\text { Реорганізація - перетворення організаційної структури і управління } \\
\text { підприємством при збереженні основних засобів, виробничого потенціалу } \\
\text { підприємства }\end{array}$ \\
\hline & Співвідношення „реструктуризація і реінжиніринг” \\
\hline $\begin{array}{l}\text { М.Хаммер, } \\
\text { Дж.Чампі }\end{array}$ & $\begin{array}{l}\text { Реіжиніринг бізнес-процесів - фундаментальне переосмислення і } \\
\text { радикальне перепроектування бізнес-процесів для досягнегнення істотних } \\
\text { покращень в основних показниках діяльності підприємства. }\end{array}$ \\
\hline Андрущак 6 . & $\begin{array}{l}\text { Реіжиніринг - глобальні перетворення у сфері організації виробництва, } \\
\text { управління та збуту продукції в рамках реструктуризації. }\end{array}$ \\
\hline Валдайцев С.В. & $\begin{array}{l}\text { Реінжиніринг - особлива процедура, що передує процедурам } \\
\text { реструктуризації (фінансової) і реорганізації суб’єкта господарювання }\end{array}$ \\
\hline $\begin{array}{l}\text { Райзберг Б.А., } \\
\text { Стародубцева }\end{array}$ & Реіжиніринг - процес модернізації раніше реалізованих технічних рішень \\
\hline
\end{tabular}


Формування i реалізація процесу реструктуризації підприємств $\epsilon$ складним i тривалим процесом, що включає сукупність організаційноекономічних, виробничих, соціально-психологічних, інвестиційних і нормативно-правових компонентів, що дозволяють забезпечити узгоджене функціонування і розвиток існуючих структурних елементів системи в цілому, що адаптуються до умов зовнішнього середовища.

\section{Висновки 3 даного дослідження і перспективи подальших розробок за} даним напрямом. Для більшості підприємств й наразі залишається відкритим питання, яким же чином проводити реструктуризацію, адже єдиного підходу до реалізації процесу реструктуризації не існує, проте, незалежно від того, в рамках якого підходу здійснюється реструктуризація підприємства, необхідно правильно визначати на яких принципах бути здійснюватися перетворення, які методи і моделі будуть застосовуватися.

Подальшим етапом дослідження повинно стати дослідження механізмів і аналіз моделей реструктуризації підприємства, також розробка алгоритму реструктуризаційних перетворень.

\section{Перелік посилань}

1. Одінцова О. Г. Теоретичні основи реструктуризації підприємств. Бізнес-інформ. 2013. №11. С.302-307.

2. Юн Г. П., Таль Г. К., Григорьев И. И. Внешнее управление на несостоятельном предприятия : учебное пособие. М. : Дело, 2003. 250 с.

3. Кордан К., Фолмен Т., Вандерборт М. Пять важных подходов к осуществлению реструктуризации. Маркетинг. 1999. №3. С.109-113.

4. Бикеева М. В. Систематизация научных взглядов на реструктуризацию предприятия. Проблемы современной экономики. 2011. №2. С.139-142.

5. Дмитриев М. Перспективы экономических реформ в России. Bonpocbl экономики. 2005. №5. С.52-56.

6. Комар Н. Г. Концепція побудови механізму реструктуризації підприємства. Бізнес-інформ. 2014. №10. С.260-267.

7. Крисько Ж. Л. Сутність та види реструктуризації підприємств. Науковий вісник Ужгородського національного університету . Сер.: Економіка. - Ужгород: Вид-во УНУ. 2009. Спецвипуск 28. Ч. II. С.71-76.

8. Безделов С. А. Управление процессами реструктуризации и реинжиниринга предприятий в переходной экономике : Дис. ... канд. экон. наук : 08.00.05. Москва, 2000. 161 с. 
9. Грязнова А. Г. Оценка стоимости предприятия (бизнеса) / под ред. А.Г. Грязнова, А. М. Федотова, М.А. Эскиндаров, Т. В. Тазихина, Е. Н. Иванова, О.Н. Щербакова. М. : Интерреклама, 2003. 544 с.

10. Мазур И. И., Шапиро В.Д. Реструктуризация предприятий и компаний. Справочное пособие. М.: Высшая школа, 2000. 587 с.

11. Королькова Е. М. Реструктуризация предприятий: учеб. пособие / Е.М. Королькова, Тамбов : Узд-во Тамб. ГТУ, 2007. 80 с.

12. Бикеева М. В. Систематизация научных взглядов на реструктуризацію предприятия. Проблемы современной экономики. 2011. №2. С.139-142.

\section{References}

1.Odintsova, O. H. (2013), The theoretical basis of enterprise restructuring [Teoretychni osnovy restrukturyzatsii pidpryiemstv], Business Inform, No 11, P.302307.

2. Jun ,G. P., Tal', G. K., Grigor'ev, I. I. (2003), External management of the enterprise [Vneshnee upravlenie na nesostojatel'nom predprijatija], tutorial, M., It's a matter, $250 \mathrm{p}$.

3. Kordan, K. (1999), Five important approaches to restructuring [Pjat' vazhnyh podhodov k osushhestvleniju restrukturizacii], Marketing, M., No 3, P.109113.

4. Bikeeva, M. V. (2011), Systematization of scientific views on enterprise restructuring [Sistematizacija nauchnyh vzgljadov na restrukturizaciju predprijatija], Problems of the modern economy, No 2, P.139-142.

5. Dmitriev, M. (2005), Prospects for economic reforms in Russia [Perspektivy jekonomicheskih reform v Rossii], Economics, No 5, P.52-56.

6. Komar, N. H. (2014), Concept of construction of the mechanism of enterprise restructuring [Kontseptsiia pobudovy mekhanizmu restrukturyzatsii pidpryiemstva], Business Inform, No 10, P.260-267.

7. Krysko, Zh. L. (2009), Essence and types of restructuring [Sutnist ta vydy restrukturyzatsii pidpryiemstv], Scientific herald of Uzhgorod National University. Sir: Economy. Uzhgorod: View of the UNU, Special issue 28, Ch. II, P.71-76.

8. Bezdelov, S. A. (2000), Management of processes of restructuring and reengineering of enterprises in the transition economy [Upravlenie processami restrukturizacii i reinzhiniringa predprijatij $\mathrm{v}$ perehodnoj jekonomike]: Dis ... Candidate econ Sciences: 08.00.05, Moscow, 161 p.

9. Grjaznova, A. G. (2003), Valuation of the enterprise (business) [Ocenka stoimosti predprijatija (biznesa)], M. : Inter-advertising, 544 p.

10. Mazur, I. I. (2000), [Restrukturizacija predprijatij i kompanij], Reference book, M .: Higher school, 587 p.

11. Korol'kova, E. M. (2007), Restructuring of enterprises [Restrukturizacija predprijatij], Tambov: Umbro Tambov GTU, $80 \mathrm{p}$.

12. Bikeeva, M. V. (2011), Systematize the scientific views on the restructuring of the enterprise [Sistematizacija nauchnyh vzgljadov na restrukturizaciju predprijatija], Problems of the modern economy, No 2, P.139-142. 


\section{КИРчаТа І. М. ТЕОРЕТИЧНІ АСПЕКТИ РЕСТРУКТУРИЗАЦЇ̈ ПІДПРИЄМСТВА ЯК ЕКОНОМІЧНОЇ КАТЕГОРІЇ}

Mema - визначення поняття реструктуризації підприємства, дослідження взаємозв'язку 3 суміжними категоріями (реорганізація, реформування, реінжиніринг). Методика дослідження. Для досягнення поставленої мети у науковій роботі були використані такі загальнонаукові та спеціальні методи і прийоми дослідження: методи узагальнення та абстрагування - для дослідження категоріального апарату процесу реструктуризації, реорганізації, реформування підприємств; метод аналізу i синтезу - для виявлення взаємозв'язку категорій «реформування - реструктуризація - реорганізація реінжиніринг». Результати. У статі розглянуто процес реструктуризації як інструмент адаптації підприємства до змін в зовнішньому середовищі. Визначено, що процес реструктуризації має забезпечувати ефективну структуру та систему управління, а також задовільний рівень конкурентоспроможності підприємства в цілому. Реалізація програми реструктуризації підприємства передбачає розробку та дотримання комплексу заходів на основі аналізу його поточного стану та наявного рівня конкурентного потенціалу. Будучи актуальним явищем реструктуризація залишається дискусійною категорією, а тому єдиного підходу до вирішення проблем реструктуризації підприємств наразі не існує, при цьому переважна більшість публікацій не має універсальної методології, системності, цілісності і несуперечності. Дослідженню проблематики реструктуризації господарських суб'єктів присвячено наукові роботи багатьох вітчизняних та зарубіжних науковців, проте й досі виникають суперечності щодо існування взаємозв'язку 3 суміжними категоріями (реорганізація, реформування, реінжиніринг), а виокремлення основних підходів в трактуванні категорії «реструктуризація» й наразі актуальне. Відсутність єдиного підходу до змісту i сутності реструктуризації в категоріальному апараті обумовило необхідність розділити всі ці поняття, при цьому спробувати водночас поєднати їх в єдиній системі. Подальшим етапом дослідження повинно стати дослідження механізмів і аналіз моделей реструктуризації підприємства, також розробка алгоритму реструктуризаційних перетворень. Наукова новизна. Обгрунтовано взаємозв'язок i взаємозумовленість в системі категорій «реформування», «реорганізація», «реструктуризація», що на відміну від існуючих, дозволяє удосконалювати процедуру адаптації підприємства до факторів зовнішнього середовища, шляхом розробки $\mathrm{i}$ реалізації стратегії комплексної реструктуризації, заснованої на ефективному використанні конкурентного потенціалу. Практична значущість полягає у тому, що отримала подальший розвиток система взаємозв'язку категорій «реформування - реструктуризація реорганізація - реінжиніринг» 3 урахуванням наукових інтерпретацій, що дозволяє визначати їх роль та місце при виявленні впливу та взаємозалежності у відповідності до направленості господарчої діяльності підприємства

Ключові слова: реструктуризація, комплексна реструктуризація, принципи реструктуризації, конкурентоспроможність підприємства, конкурентний потенціал 


\section{РЕФЕРАТИ РЕФЕРАТЫ ABSTRACTS}

\section{КИРчаТая И. Н. ТЕОРЕТИЧЕСКИЕ АСПЕКТЫ РЕСТРУКТУРИЗАЦИИ ПРЕДПРИЯТИЙ КАК ЭКОНОМИЧЕСКОЙ КАТЕГОРИИ}

Цель - определение понятия реструктуризации предприятия, исследование взаимосвязи со смежными категориями (реорганизация, реформирование, реинжиниринг). Методика исследования. Для достижения поставленной цели в научной работе были использованы такие общенаучные и специальные методы и приемы исследования: методы обобщения и абстрагирования - для исследования категориального аппарата и процесса реструктуризации, реорганизации, реформирования предприятий; метод анализа и синтеза - для выявления взаимосвязи категорий «реформирование реструктуризация - реорганизация - реинжиниринг». Результаты. В статье рассмотрен процесс реструктуризации как инструмент адаптации предприятия к изменениям во внешней среде. Определено, что процесс реструктуризации должен обеспечивать эффективную структуру и систему управления, а также удовлетворительный уровень конкурентоспособности предприятия в целом. Реализация программы реструктуризации предприятия предусматривает разработку и соблюдение комплекса мероприятий на основе анализа его текущего состояния и имеющегося уровня конкурентного потенциала. Будучи актуальным явлением реструктуризация остается дискуссионной категорией, поэтому единого подхода к решению проблем реструктуризации предприятий пока не существует, при этом подавляющее большинство публикаций не имеет универсальной методологии, системности, целостности и непротиворечивости. Исследованию проблематики реструктуризации хозяйственных субъектов посвящены научные работы многих отечественных и зарубежных ученых, однако до сих пор возникают противоречия относительно существования взаимосвязи со смежными категориями (реорганизация, реформирование, реинжиниринг), а выделение основных подходов в трактовке категории «реструктуризация» и сейчас актуально. Отсутствие единого подхода к содержанию и сущности реструктуризации в категориальном аппарате обусловило необходимость разделить все эти понятия, при этом попробовать одновременно совместить их в единой системе. Следующим этапом исследования должно стать исследование механизмов и анализ моделей реструктуризации предприятия, а также разработка алгоритма реструктуризационных преобразований. Научная новизна. Обоснована взаимосвязь и взаимообусловленность в системе категорий «реформирование», «реорганизация», «реструктуризация», которая позволяет совершенствовать процедуру адаптации предприятия к факторам внешней среды, путем разработки и реализации стратегии комплексной реструктуризации, основанной на эффективном использовании конкурентного потенциала. Практическая значимость заключается в том, что получила дальнейшее развитие система взаимосвязи категорий «реформирование - реструктуризация - реорганизация реинжиниринг» с учетом научных интерпретаций, позволяющая определять их 
роль и место при выявлении влияния и взаимозависимости в соответствии с направленностью хозяйственной деятельности предприятия.

Ключевые слова: реструктуризация, комплексная реструктуризация, принципы реструктуризации, конкурентоспособность предприятия, конкурентный потенциал

\section{Kirchataya I. N. THEORETICAL ASPECTS OF ENTERPRISES RESTRUCTURING AS AN ECONOMIC CATEGORY}

Purpose - The aim is to define the concept of enterprise restructuring and research the relationship with related categories (reorganization, reforming, reengineering). Methodology of research. To achieve the goal in the scientific work general scientific and special research methods were used: methods of generalization and abstraction - to investigate the categorical apparatus and the process of the enterprises restructuring, reorganizing, reforming; method of analysis and synthesis to identify the relationship between the categories of "reforming - restructuring reorganization - reengineering". Findings. The article describes the process of restructuring as a tool to adapt an enterprise to changes in the external environment. It was determined that the restructuring process should provide an effective structure and management system, as well as a satisfactory level of the enterprise competitiveness. The implementation of the enterprise restructuring program provides for the development and maintenance of the measures set basing on an analysis of its current state and the existing level of competitive potential. Being an actual phenomenon the restructuring is a discussion category, so that's why unified approach to solve the enterprise restructuring problems has been not existed yet. While the vast majority of publications does not have a universal methodology, systemicity, integrity and consistency. Researches of many domestic and foreign scientists are devoted to the enterprises restructuring, but there are still contradictions regarding the existence of interrelations with related categories (reorganization, reforming, reengineering). There are still contradictions regarding the existence of interconnection with related categories (reorganization, reformation, reengineering), and the main approaches separation is still relevant in the interpretation of the category "restructuring". The lack of a unified approach of content and nature of the restructuring brings to the need to share all these concepts in the categorical apparatus, while trying to combine them into a single system simultaneously. The next stage of the research should be the investigation of mechanisms and analysis of enterprise restructuring models, as well as the development of an algorithm for restructuring transformations. Originality. In the article the interrelation and interdependence in the system of categories "reform", "reorganization", "restructuring" was justified, which allows to improve the process of adapting an enterprise to environmental factors by developing and implementing an integrated restructuring strategy which based on the effective use of competitive potential. Practical value. The system of interrelation of the categories "reform - restructuring reorganization - reengineering" was developed further, taking into account scientific interpretations, which allows to determine their role and place in identifying 
influence and interdependence in accordance with the direction of the enterprise's economic activity.

Keywords: restructuring, comprehensive restructuring, principles of restructuring, enterprise competitiveness, competitive potential.

\section{Відомості про авторів}

Кирчата Ірина Миколаївна - кандидат економічних наук, доцент, Харківський національний автомобільно-дорожній університет, доцент кафедри економіки i підприємництва, м. Харків, Україна; e-mail: kirchatayairina@gmail.com; ORCID ID: https: //orcid.org/0000-0002-0270-1586. Моб. 0506690096.

Кирчатая Ирина Николаевна - кандидат экономических наук, доцент, Харьковский национальный автомобильно-дорожный университет, доцент кафедры экономики и предпринимательства, г.Харьков, Украина

Kirchataya Irina Nikolaevna - Candidate of Science (Economics), Associate Professor, Kharkiv National Automobile and Highway University, Associate Professor, Department of Economics and Entrepreneurship, Kharkiv, Ukraine 